UDC 004.9:378.147: 81'243'373

Olena Stryzhak ${ }^{1}$, Ganna Krapivnyk ${ }^{2}$

${ }^{1}$ Simon Kuznets Kharkiv National University of Economics, Kharkiv, Ukraine

${ }^{2}$ H. S. Skovoroda Kharkiv National Pedagogical University, Kharkiv, Ukraine

\title{
THE APPLICATION OF MOODLE PLATFORM FUNCTIONS TO DEVELOP FOREIGN LANGUAGE LEXICAL COMPETENCY
}

DOI: $10.14308 /$ ite 000733

The paper discusses the features of developing foreign language lexical competency while applying the Moodle platform. The development of the foreign language lexical competency is considered as a case study of teaching the Service Marketing course to full-time master's degree students at Simon Kuznets Kharkiv National University of Economics. The case shows the distance educational course of Service marketing, including the description of its content and structural elements that promote professional competencies. The research proves the need to apply information communication technologies provided by Moodle functionality in developing foreign language lexical competency. The elements of the Moodle information platform that enable to form student's professional terminology minimum are described.

Lexical competency implies not only clarifying etymology and semantics of a language sign but also studying the specifics of its use depending on the content. Therefore, it is offered to educators to apply foreign language materials and develop professional lexical competency. This process is exemplified by the analysis of a television commercial in English and the evaluation of the advert efficiency. The commercial evaluation procedure includes its viewing and identifying the means and methods of its impact on the consumer's consciousness, which involves learning and analyzing language-related information. It was found out that, in addition to the development of course-related professional competencies, watching and analyzing video materials encourages the development of speaking skills and enriches students' vocabulary.

The benefits and drawbacks of using the Moodle environment for lectures, seminars, students' individual work, academic performance and knowledge assessment are laid out.

Keywords: academic subject; distance learning, professional competency; foreign language competency; Moodle platform

\section{Introduction}

Currently, most developed economies worldwide are dominated by the service sector, where its specific weight has been steadily growing over years. Unessential production has been not only generating a significant part of the GDP, but also creating new jobs, thus encouraging the development of other industries of the economy. Therefore, the research into the issues of services area functioning is topical and relevant while the acquisition of respective knowledge and the development of skills related to business operations on the services market are a necessary pre-condition for the professional success in this field.

The demand for studying Service Marketing is determined by the tough competition on global markets and the crisis of overproduction market research issues have been gaining significance. The point is that they encourage the use of marketing ideas and principles in practical routine contexts. Further, the acquisition of theoretical basics and the development of practical skills of their application in the current market economic conditions are vital for future professionals.

It is worth mentioning that the globalization of socioeconomic relations and the Ukrainian integration into the European community along with professional competencies in various 
specializations have been activating and requiring the development of special skills and foreign language competencies. The knowledge of a foreign language improves competitiveness on labor market, facilitates labor mobility, and enables more efficient use of information, software and literary resources, thus promoting chances for a higher income level. These objective pre-conditions determine the need to teach academic subjects in English, focusing on foreign language competencies. A most effective means of forming these competencies in the academic environment is via Moodle platform.

The objective pre-conditions for the application of Moodle platform functions when teaching academic courses at Simon Kuznets Kharkiv National University of Economics include the provision of such opportunities for students as: the combination of study, in-service training and work; studying at more than one higher education institution simultaneously; gaining knowledge and skills by distance learning; doing tasks remotely or offline; choosing the convenient time to work on the educational materials etc.

The Moodle educational platform is a system oriented towards the implementation of full-time distance learning as well as the application of individual elements of distance learning in the offline education process. The means of the Moodle information platform give students opportunities to get new knowledge and skills owing to its diverse functionality and the possibility to study distantly.

\section{Background}

Recently, the issues of using information communication technologies in the academic studies have been in the focus of researchers' attention. For instance, Bodnenko D. discussed the matter of education digitalization in the context of modern trends of the higher school development (Bodnenko, 2013). Dyshko O., Zubekhina T., Pavlyshyna N. considered the situation with the introduction of information communication technologies in bachelor degree distance learning (based on the experience gained in specializations "Tourism" and "Social work") in higher education institutions, and their efficiency and effectiveness were singled out (Dyshko et al., 2017). The specific features of launching innovative forms and methods of education in the conventional professional education were outlined, while the opportunities of using the problem-based method when applying network technologies were analyzed (Bolubash, 2013). The focus was made on the implementation of the missed students' studying concept basing on the academic information environment and using electronic guidelines and course packages (Kobysia, 2017). The use of interactive technologies to develop students' foreign language communicative competency while studying the English language was considered, inter alia, by Fahrutdinova R. A, Yarmakeev I. E. and Fakhrutdinov R. R. (Fahrutdinova et al., 2014).

Accordingly, as Ukraine is integrating into the global educational system, it is relevant for researchers to further elaborate the concepts of developing foreign language competencies using cutting edge information communication technologies. In that respect, Dolyna A. V. analyzed the ways of improving phonetic competency of pre-service English teachers applying the Moodle course management system. A reflexive model of improving phonetic competency while working individually was suggested (Dolyna, 2019). The scholar also considered the features of building English language professionally-oriented lexical competency using information communication technologies (Ivanova, 2014). Specific aspects of arranging mixed learning of German practical phonetics in the Moodle virtual academic environment was discussed (Beskorsa, 2017). A model of using mobile technologies as a tool to form foreign communicative competencies was offered (Osipova et al., 2016). Solomakha A. well-grounded the need to use digital technologies in the development of foreign language communicative competencies of pre-service teachers (Solomakha, 2019). The processes of establishing and developing foreign language communicative lexical competency have been in the focus of many scholars. In particular, Chainikova G. R., Zatonskiy A.V., Mitiukov N. W. and Busygina H. L. suggested a method of developing lexical competency in 
second-language learning based on the terminological thesaurus and the glossary of program terms (Chainikova et al., 2018). The opportunities of using communicative and competency approaches to shaping foreign language communicative competency among non-philological students were studied by Bydrina O. G., Dolzhenko S. G., Yurinova Ye. A. (Byrdina et al., 2018). Potiuk I. Ye. pointed out the main steps in forming students' English lexical competency in a higher education institution, and the researcher also analyzed characteristic features of its acquisition (Potiuk, 2016). Horbatiuk L., Alieksieieva H., Kravchenko N., Lipych V., \& Rozumna T. provided evidence to the need of applying mobile technologies in foreign language studies to improve the level of lexical competency in non-philological students (Horbatiuk et al., 2019). Gladka O. considered the features of the foreign language lexical competency development among philological students (Gladka, 2018). Dolynskyi Ye. identified theoretical basics for the methodology of developing foreign language lexical competency among students (Dolynskyi, 2015). Shmidt V. V. specified the features and stages of developing a foreign language lexical competency among non-philological students based on interactive activities and tasks (Schmidt, 2009). Zaichenko I. A. offered a model of formation a foreign language lexical competency in the process of training professionally oriented speaking of future metallurgists (Zaichenko, 2014). Ternavska L. M., Shauerman O. A. considered the problems of formation non-philological students' lexical competency using English phraseology; the authors described an algorithm of the activities, ensuring gradual acquisition, practice and further use of phraseological units by students in their speech production (Ternavs'ka, Shauerman, 2015). Smolina S. V. identified the stages and characterized the means of forming lexical competency. The researcher also offered a set of tasks for its development (Smolina, 2010). Amelina S. M. specified lexical competency as an important element of the foreign language communicative competency of pre-service philologists and suggested the stages of its development (Amelina, 2014).

At the same time, certain disunity of theoretical and methodological research works can be observed regarding the development of professional and language competencies of higher education students. In this context an important task is for non-philological undergraduate and graduate students to develop foreign language lexical skills, in particular, to learn dedicated vocabulary. The improvement of foreign language competencies is an essential condition for a future successful career, and, consequently, the study of the foreign language lexical competency issues is topical and relevant.

The aim of this research is to identify the features of applying the Moodle educational platform to develop foreign language lexical competency using the case of teaching the Service Marketing course in the English language.

\section{Results of the research}

Service Marketing is an academic course, offered as optional to full-time master's degree students. Its place in the curriculum is shown in Table № 1.

Table № 1

Structural-logical scheme of the discipline

\begin{tabular}{|l|l|}
\hline \multicolumn{1}{|c|}{ Previous subjects } & \multicolumn{1}{c|}{ Following subjects } \\
\hline $\begin{array}{l}\text { World economy and international economic } \\
\text { relations }\end{array}$ & $\begin{array}{l}\text { Methodology and organization of scientific } \\
\text { research }\end{array}$ \\
\hline Marketing & Internet-Marketing \\
\hline Economics of the enterprise & Cross-cultural communicative management \\
\hline
\end{tabular}


The objective of the Service Marketing academic course is to provide students with theoretical knowledge and develop their practical skills in corporate marketing activities in service industry, service market research and surveying, specifying the areas of service industry corporate development in the current conditions and the application of a set of marketing means in their professional work.

The Service Marketing course comprises three ECTS credits, while the total duration of the course is 150 hours (see Table № 2).

Table № 2

Academic course time distribution, hours

\begin{tabular}{|l|ll|}
\hline Year & 5 & \\
\hline Term & 1 & 20 \\
\hline ECTS Credits & 3 \\
\hline \multirow{2}{*}{ Classroom learning } & Lectures & 20 \\
\cline { 2 - 3 } & Seminars, practical lessons & 110 \\
\hline Individual work & & \\
\hline Final control & test \\
\hline
\end{tabular}

The need to apply the Moodle platform as an information medium is also determined by the fact that the scope of students' individual work prevails over the classwork hours. The curriculum implies that students individually work on the materials, offered and provided in Moodle. Additionally, the course package includes guidelines on individual activities, methodical work, practical (seminar) tasks, tests for module and final control, as well as the questions for self-check and preparation for seminar classes.

The structure of all academic subjects at Simon Kuznets Kharkiv National University of Economics is unified. For example, every subject must include a technological chart (syllabus), correspondent modules, student's progress assessment system, including the distribution of points by forms, methods and weeks of studying an academic course (Fig. 1).

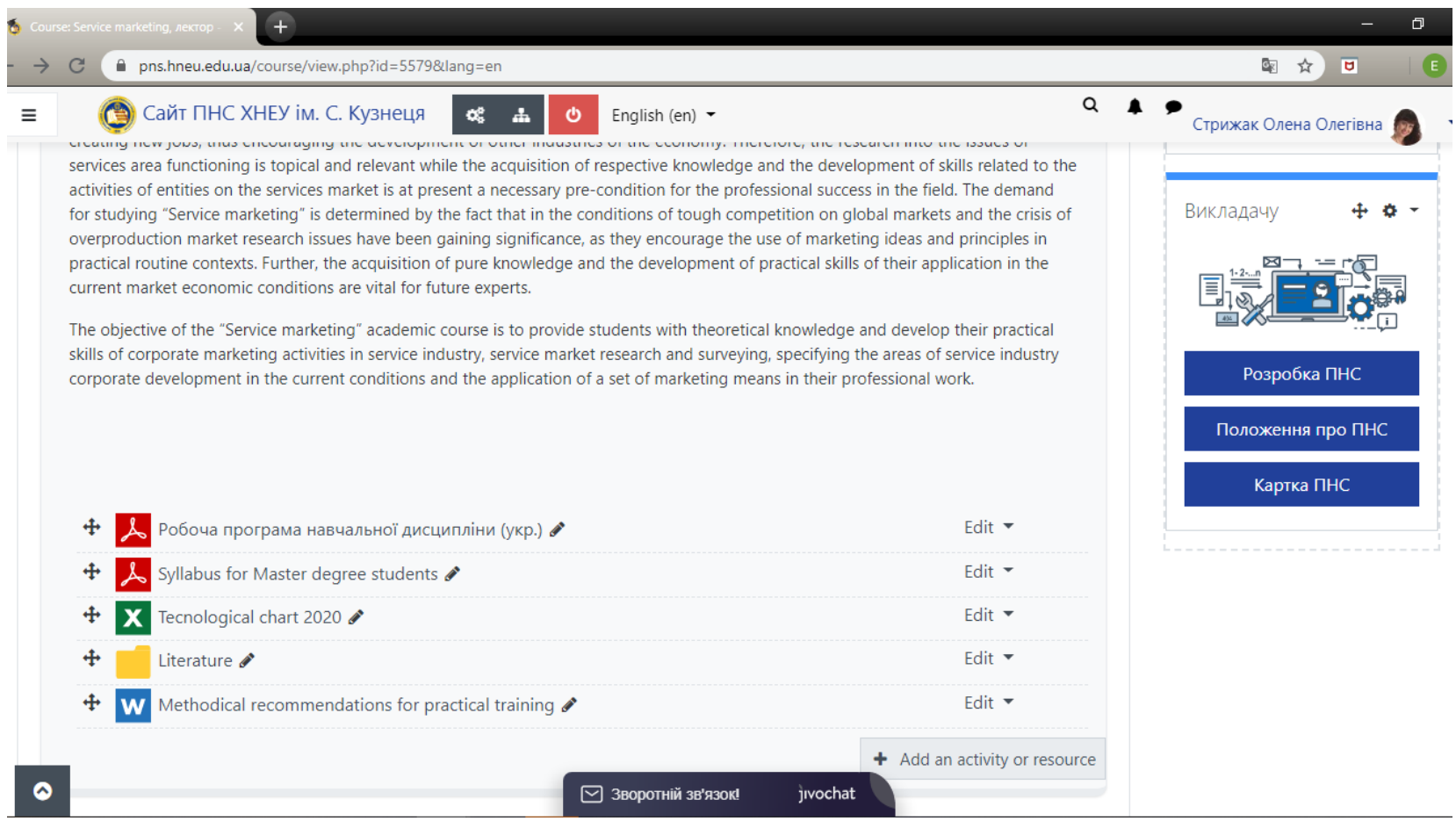

Fig. 1. A fragment of the Service Marketing course on Moodle platform

Moreover, this information communication educational platform provides the opportunity to 
organize ongoing assessment of students' knowledge and general performance by testing and doing interactive tasks.

Distance learning in the Moodle educational medium may be performed out of the classroom, as well as an additional tool in the classroom, particularly, tests or tasks, which imply fast responses. An essential benefit of using the Moodle information medium is a possibility to provide feedback for both students and teachers, which provides the opportunity to ask questions directly or in forums, as well as to advise and provide tutorials online, in chats or in scheduled video calls and meetings.

The whole content scope of the educational materials for the Service Marketing course is divided into two modules: "The Concept and Features of Marketing in Service Industry" and "The Set of Corporate Marketing Activities in Service Industry". Upon the completion of the course master's degree students will have developed the professional competencies below (see Table № 3).

Table № 3

Professional competencies and academic outcomes of completing the Service Marketing course

\begin{tabular}{|c|c|c|}
\hline \multicolumn{3}{|c|}{ CONTENT MODULE 1 . The concept and features of marketing in service industry } \\
\hline Topics & Competencies & $\begin{array}{c}\begin{array}{c}\text { Educational } \\
\text { outcome }\end{array} \\
\end{array}$ \\
\hline $\begin{array}{l}\text { Topic 1. Services industry in } \\
\text { modern society }\end{array}$ & \multirow{2}{*}{$\begin{array}{l}\text { The assessment of environmental factors } \\
\text { impact on services market }\end{array}$} & \multirow{5}{*}{$\begin{array}{l}\text { Knowledge, abilities } \\
\text { and skills in service } \\
\text { market functioning } \\
\text { and development }\end{array}$} \\
\hline $\begin{array}{l}\text { Topic 2. Services market and its } \\
\text { features }\end{array}$ & & \\
\hline $\begin{array}{l}\text { Topic 3. Specifics of services } \\
\text { market }\end{array}$ & $\begin{array}{l}\text { The ability to use marketing tools to } \\
\text { study the service industry }\end{array}$ & \\
\hline $\begin{array}{l}\text { Topic 4. Market research into } \\
\text { services industry }\end{array}$ & \multirow{2}{*}{$\begin{array}{l}\text { The ability to categorize and segment } \\
\text { services market according to the selected } \\
\text { segmentation criteria }\end{array}$} & \\
\hline $\begin{array}{l}\text { Topic 5. Consumers' behavior } \\
\text { on services market }\end{array}$ & & \\
\hline \multicolumn{3}{|c|}{ CONTENT MODULE 2. The set of corporate marketing activities in service industry } \\
\hline $\begin{array}{l}\text { Topic } 6 . \text { The quality of services } \\
\text { and service standards }\end{array}$ & $\begin{array}{l}\text { Assessment and analysis of service } \\
\text { quality and competitiveness }\end{array}$ & \multirow{5}{*}{$\begin{array}{lr}\text { Knowledge, } & \text { abilities } \\
\text { and skills in } & \text { services } \\
\text { rendering } & \text { and } \\
\text { provision } & \end{array}$} \\
\hline $\begin{array}{l}\text { Topic 7. Service rates and } \\
\text { pricing principles }\end{array}$ & Rates and pricing principles & \\
\hline $\begin{array}{l}\text { Topic } 8 \text {. Corporate marketing } \\
\text { strategy in service industry }\end{array}$ & $\begin{array}{l}\text { The development of a marketing } \\
\text { development strategy for business } \\
\text { entities in service industry }\end{array}$ & \\
\hline $\begin{array}{l}\text { Topic } 9 \text {. Communicative policy } \\
\text { in service industry }\end{array}$ & $\begin{array}{l}\text { Identification of features and specifics of } \\
\text { services as products }\end{array}$ & \\
\hline Topic 10. Services promotion & $\begin{array}{l}\text { The selection of marketing promotion } \\
\text { tools }\end{array}$ & \\
\hline
\end{tabular}

According to Bolubash N. M., professional competency is an integral quality of a personality that shows the ability of a trained person to solve professional problems and tasks, emerging in real-life professional environment based on the available personal features: knowledge, abilities, skills, background, expertise, capabilities, and values as the total of competencies (Bolubash, 2009). An important component of the professional competence among the students majoring in tourism is a foreign language competency.

Lexical competency is understood as the person's ability to produce utterances and texts as well as understand other people's speech, based on the complex and dynamic interaction of 
corresponding skills, knowledge and lexical awareness (Bigich et al., 2013: 215). In other words, it is the ability not only to understand individual lexical units, but perceive the whole context of cohesive speech. Furthermore, it is the ability to express personal thoughts in the way understandable to others. Lexical competency is a complex category and according to Nikolayev S. Yu.; it involves the knowledge and ability to use the vocabulary, including lexical (phraseological units: speech patterns; idioms; set expressions that are ready-made integrated units and are used as single and indivisible items; colloquialisms and collocations; words, belonging to different categories: nouns, verbs, adjectives, adverbs; closed paradigmatic lexical groups) and functional grammatical words (articles, numerals, demonstrative pronouns, personal pronouns, interrogative, relative and possessive pronouns, prepositions, auxiliary verbs, conjunctions and particles) (Nikolaeva, 2003: 166-167).

Lexical competency is used basing on certain rules of perception of language as well as national, model, ethnical, and religious patterns, specific features of national mentality and world outlook. Yarema I. A focuses on the importance of well-established standards to form and use lexical competency. The researcher notes that the lexical competency is "the ability of an individual to use language vocabulary on the basis of lexical knowledge, instantly taking from the long memory the standard of the word depending on the particular language task, appropriately using the chosen expressions, sayings, proverbs and phraseological units within the framework of professional development, as well as to support the functioning of these skills at the required level and to continuously monitor the lexical content of the speech" (Yarema, 2012). According to the definition provided by Smolina S.V. lexical competency is the person's ability to express his or her ideas correctly and understand others respectively (Smolina, 2010: 16). Therefore, lexical competency comprises many elements, shaping its main features - language understanding and the ability to express ideas and thoughts clearly.

The process of developing lexical competency is gradual and consists of several stages, e.g., according to Amelina S. M.:

- semantization (introduction of new lexical material);

- automation (developing and primary drilling the skills in using lexical units);

- reproduction (improvement of the skills and the development of the ability to use newly-acquired lexical units in various speech activities) (Amelina, 2014).

The enrichment of vocabulary for the development of foreign language lexical competency may be straightforward and explicit by learning certain terms or word combinations, or implicit, by learning in conversations and in process of exchanging views.

The foreign language lexical competency is developed via using the Moodle platform when students read and study the course glossary, its presentations, lectures, electronic textbooks etc. The acquired knowledge and skills are drilled when preparing educational materials for seminars, trainings and when doing individual tasks.

Lexical skills development starts with the introduction of new material. Then this material is thoroughly studied and revised. This stage is followed by the development of lexical skills in communicative contexts, including students' use of professional terminology during classes. Vocabulary learning primarily implies semantization of terms, i.e. the definition and finding the meanings of words, acquiring their semantics and their use in speaking and writing.

However, lexical competency is expected to include not only finding semantics and at times etymology of a lexical unit, but also studying the features of its context-dependent usage, which is especially important for the English language, rich in polysemantic words that have various meanings in different contexts and cases of use.

Studying the peculiarities of developing lexical competency, Chainikova G. R. states that the most effective means of developing lexical competency can be learner's terminological thesaurus and vocabulary, which include four key components: 1) classification part, 2) ideographic part (thesaurus), 3) glossary, and 4) bilingual vocabulary. The expansion of contexts due to the increased 
number of examples of word combinations and sentences as well as the inclusion of specially selected texts encyclopedically allows us to demonstrate how different functions of lexical items are implemented in texts. The full implementation of the functions of the learner's thesaurus and vocabulary is possible only in electronic format (Chainikova et al., 2018).

It is to be noted that Moodle contains the elements, whose use may be oriented towards developing foreign language lexical competency. These elements include:

Glossary - to study the key notions of professional terms and concepts, students can individually extend and expand it while doing the course, and add the examples of using professionalisms in specific contexts;

Chat - to organize online interaction between a student and a teacher, and to arrange group activities during seminars and distance workshops;

Online page - to show educational materials, including presentations, video- and audio materials, questions and references.

The use of the above elements of the Moodle platform provides an opportunity to build students' terminological basis in a certain field, which will be useful to prepare didactic materials, and can be used further to complete the course successfully.

For instance, students are offered an activity on analyzing a television commercial in the English language and assessing this suggested advert pattern effectiveness. The assessment procedure of the commercial includes its viewing and identifying the means and techniques of its influence on consumers' minds, including those contained in wording.

References and links to the commercials are given in the rubric, and students are offered to choose one of them (Fig. 2).

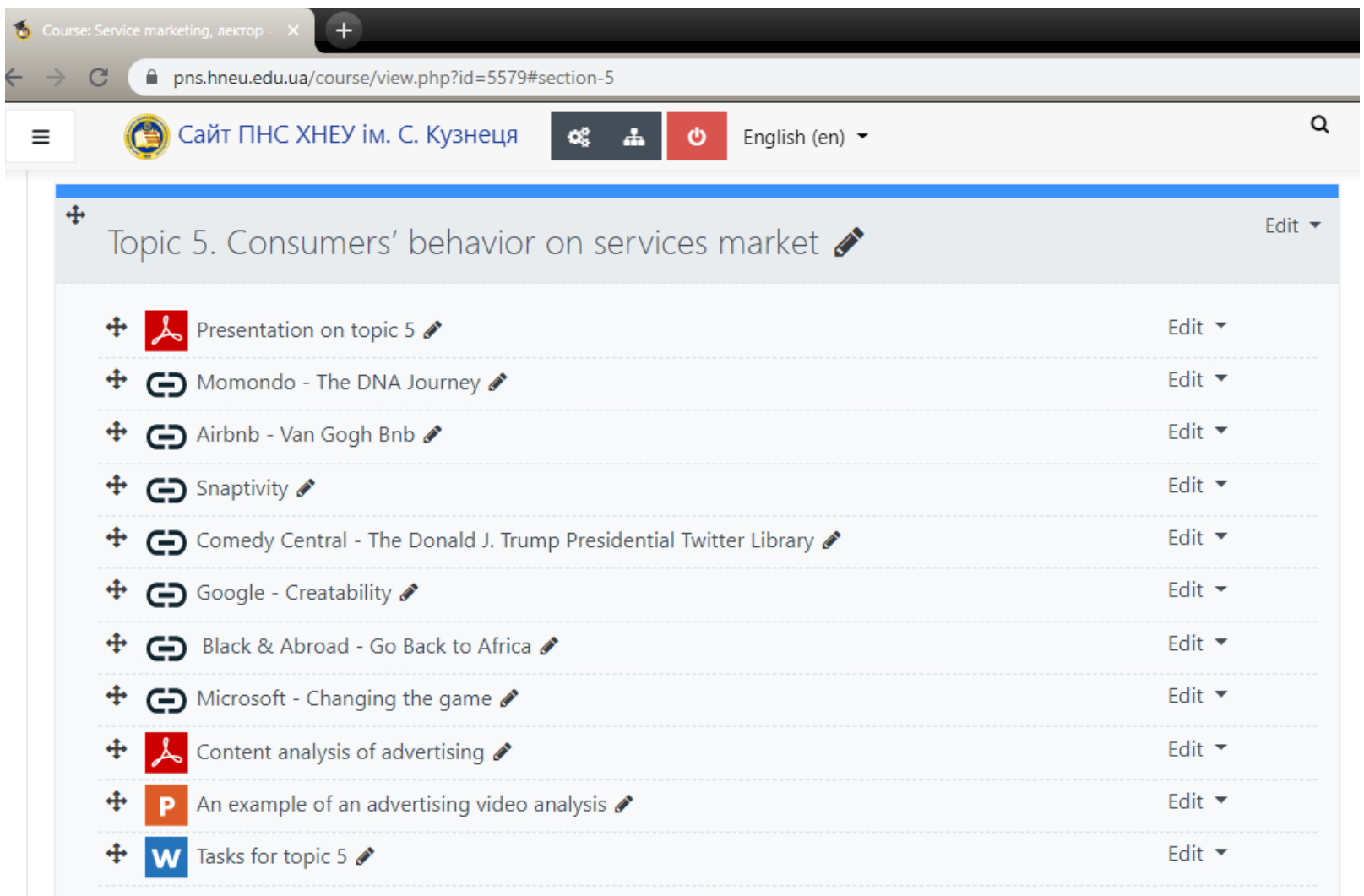

Fig. 2. An excerpt from a subject syllabus with a task

The commercials to be considered are selected according to the criterion of the availability of English native speakers' voiceover. This way, viewing the commercial given in the task (Fig. 3) 
both improves professional competencies in the subject and encourages students' foreign language lexical competency.

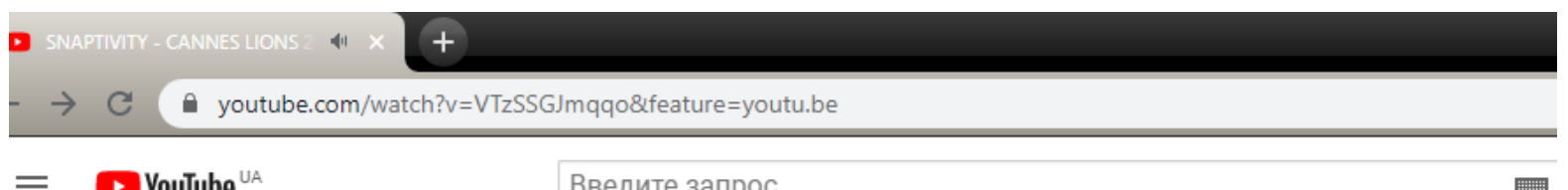

$\equiv$ YouTube $^{\text {Ua }} \quad$ Введите запрос

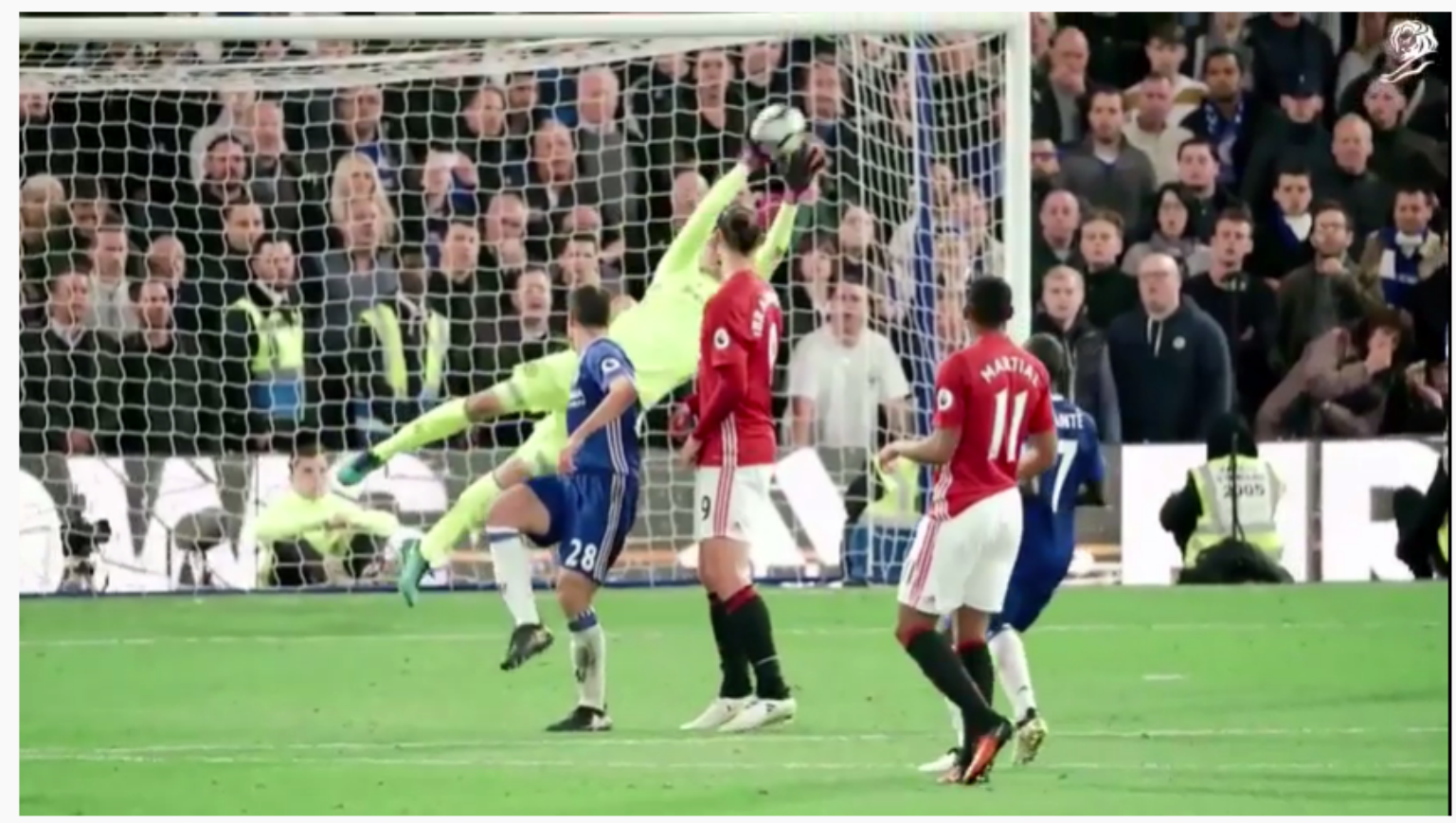

SNAPTIVITY - CANNES LIONS 2018 (Case Study)

Fig. 3. A shot from the commercial under analysis

To do the home assignment, a student should read the transcript of the commercial, which requires finding out the meaning of the new language (Table № 4).

Table № 4

Sample analysis of the commercial language element

\begin{tabular}{|l|l|}
\hline \multicolumn{1}{|c|}{ Word / Phrase } & \multicolumn{1}{c|}{ Translation } \\
\hline a stomach & шлунок, живіт \\
\hline a chest & грудна клітина \\
\hline to scream at the top of your lungs & кричати щосили \\
\hline to treasure & цінувати \\
\hline to live smth to the full & максимально прожити якийсь досвід \\
\hline to have smb's back & підстраховувати, прикривати когось \\
\hline to capture & зловити, сфотографувати \\
\hline a crowd & натовп \\
\hline to predict & передбачати \\
\hline to trigger & запускати, ініціювати \\
\hline despair & відчай \\
\hline to brag & хвалитися \\
\hline to share & ділитися \\
\hline over and over & знову і знову \\
\hline
\end{tabular}




\begin{tabular}{|l|l|}
\hline to cover & висвітлювати (подіiі) \\
\hline engagement & залучення \\
\hline to witness & бути свідком, бачити \\
\hline
\end{tabular}

In addition to doing the commercial-based analytical task, students are offered to add new vocabulary items into their subject glossary. Moodle platform functions provide this opportunity.

After the task, the student is given the follow-up task to make a report on the analysis and present findings. Upon the presentations results, group discussion is organized.

Thus, the performance of the above video commercial-based activity promotes the development of productive language skills and expands students' active vocabulary.

The development of students' lexical skills and the respective improvement of foreign language lexical competency when learning the Service Marketing course is an interactive process of all its participants.

Thus, the use of the Moodle platform on the whole and its individual modules provides an opportunity for students to develop their second language skills, namely, their foreign language lexical competency while learning a non-language-related academic course.

\section{Conclusions}

All the above considered, it is possible to point out the benefits of using the Moodle platform to develop a foreign language lexical competency. Primarily, it provides an opportunity of distance access to the course training materials from any place and at any time. The structure of educational materials is given by topics, weeks, modules and activities. The system features a wide range of possibilities to access resources and save time on searching required information. Moodle enables further studies and revision of the material as well as improves motivation and thus performance. The system monitors personal educational outcomes and allows for their comparison to the performance of other students, including the possibility to make a performance rating list. It activates educational process owing to the interactivity, the use of visual and sound features. The conversational nature of learning is supported by continuous contact with teachers and other students. Individualization and flexibility of the training process is enabled based on the level of students' basic background knowledge and age. Moodle provides a high level of material visualization (video-, audio records, the organization of audio and video meetings) and digital visualization of the training process. Possibility to accumulate information and arrange respective archives. The system has a unified, transparent, automated and convenient scoring system, as well as a performance assessment system. The flexible selection of time and rate of studying is introduced to meet personal schedule and learning capability requirements.

The main drawbacks of using the Moodle platform to develop foreign language lexical competency, apparently, include, in particular, limitations or unavailability of personal contact, but this drawback is typical of the distance learning option only. The dependence on the quality of internet connection - in case of its absence the work with Moodle information medium is impossible. The dependence on the level of the system server load - at the time of peak loads the web platform can operate slowly or fail. It is necessary to digitalize all educational materials, which requires additional efforts and time. There is a risk of hacking and unauthorized access to certain materials, e.g. test keys or problem solutions.

\section{СПИСОК ВИКОРИСТАНИХ ДЖЕРЕЛ}

1. Bodnenko, D (2013). The Role of Informatization in the Change of Higher School Tasks: the Impact on the Professional Teacher Competences. ICTERI, 281-287.

2. Дишко, О. Л., Зубехіна, Т. В., Павлишина, Н. Б. (2017). Інформаційно-комунікаційні технології в організації електронного навчання бакалаврів (на прикладі спеціальностей «Туризм» та «Соціальна робота»). Інформаційні технології $і$ засоби навчання, 59 (3). 76-86. 
3. Болюбаш, Н. М. (2013). Організаційно-методичні аспекти навчання на базі інформаційного середовища Moodle. Інформаційні технологї $і$ засоби навчання, 1 (33).

4. Кобися, А. П. (2017). Інформаційне освітнє середовище як платформа для реалізації змішаного навчання у вищих навчальних закладах. Інформаційні технологї $i$ засоби навчання, 57(1). 75-82.

5. Fahrutdinova, R., Yarmakeev, I., Fakhrutdinov, R. (2014). The formation of students? Foreign language communicative competence in learning English through interactive learning technologies (The study carried out at Kazan Federal University). English Language Teaching, 7(12), 36-46.

6. Долина, А. В. (2019). Використання системи Мoodle для вдосконалення фонетичної компетентності майбутніх учителів англійської мови. Інформаційні технології $i$ засоби навчання, 70 (2).

7. Іванова, О. А. (2014). Інформаційно-комунікаційні технології у процесі формування професійно орієнтованої лексичної компетентності. Advanced Education, 1, 21-29.

8. Бескорса, О. С. (2017). Система Moodle як засіб організації змішаного навчання практичної фонетики німецької мови. Інформаційні технології $і$ засоби навчання, 62 (6), 86-97.

9. Osipova, N., Gnedkova, O., Ushakov, D. (2016). Mobile Learning Technologies for Learning English. ICTERI, 672-679.

10. Соломаха, А (2019). Застосування словникових он-лайн тренажерів для формування іншомовної лексичної компетенції майбутнього педагога. Освітологічний дискурс, 3-4 (26-27), 143-155.

11. Chainikova, G., Zatonskiy, A., Mitiukov, N., Busygina, H. (2018). The Development of Foreign Language Lexical Competence on the Basis of a Learner's Terminological Thesaurus and Dictionary. European Journal of Contemporary Education, 7(1), 51-59.

12. Бырдина, О. Г., Долженко, С. Г., Юринова, Е. А. (2018). Формирование иноязычной коммуникативной компетенции у студентов нефилологических профилей подготовки посредством content-based active speaking technology. Вестник Новосибирского государственного педагогического университета, 8 (4), 7-25.

13. Потюк, I. Є. (2016). Методика формування іншомовної лексичної компетентності студентів в умовах стратегічного вивчення іноземної мови (комунікативний аспект). Наукові записки Національного університету "Острозька академія». Серія "Філософія", 62, 280-283.

14. Horbatiuk, L., Alieksieieva, H., Kravchenko, N., Lipych, V., Rozumna, T. (2019). Use of Mobile Applications for Foreign Language Lexical Competence Formation. Journal of History Culture and Art Research, 8 (3), 113-124.

15. Гладка, О. (2018). Особливості розвитку іншомовної лексичної компетентності студентів-філологів. Наукові записки. Серія: Філологічні науки, 165, 455-459.

16. Долинський, Є. В. (2015). Методика формування іншомовної лексичної компетентності за допомогою посібника елективного курсу "Моя Франція". Проблеми сучасного підручника, 15 (1), 179-186.

17. Шмідт, В. В. (2009). Етапи формування іншомовної лексичної компетенції студентів немовних спеціальностей. Вісник ЧДУ ім. Петра Могили. Наукові праці, 95 (108), 141-145.

18. Зайченко, I. А. (2014). Модель формування англомовної лексичної компетентності майбутніх металургів у процесі навчання професійно орієнтованого говоріння. Вісник Київського національного лінгвістичного університету. Сер.: Педагогіка та психологія, 23, $119-128$.

19. Тернавська, Л. М., Шауерман, О. А. (2015). Формування іншомовної лексичної компетентності студентів немовних ВНЗ засобами фразеології. Вісник Дніпропетровського університету імені Альфреда Нобеля. Серія: Педагогіка і психологія, 1, 188-192. 
20. Смоліна, С. В. (2010). Методика формування іншомовної лексичної компетенції. Іноземні мови. 4, 16-23.

21. Амеліна, С. М. (2014). Методика формування лексичної компетенції майбутніх філологів. Вісник Дніпропетровського університету імені Альфреда Нобеля. Серія: Педагогіка і психологія, 2 (8), 9-13.

22. Болюбаш, Н. М. (2009). Теоретичні засади формування професійної компетентності майбутніх економістів. Наукові праиі: науково-методичний журнал. Педагогіка, 99 (112), $88-95$.

23. Методика навчання іноземних мов і культур: теорія і практика підручник для студ. класичних, педагогічних і лінгвістичних університетів / за заг. ред. С. Ю. Ніколаєвої. К: Ленвіт. 2013.

24. Загальноєвропейські рекомендації з мовної освіти: вивчення, викладання, оцінювання / за ред. С. Ю. Ніколаєвої. К: Ленвіт, 2003.

25. Yarema, I. (2012). Contents of the formation of English lexical competence in professionally oriented speaking of students of metallurgical specialties. Collection of scientific works «Bulletin of Zaporizhzhia National University. Pedagogical Sciences», 1 (17), 197-203.

\section{REFERENCES (TRANSLATED AND TRANSLITERATED)}

1. Bodnenko, D. (2013). The Role of Informatization in the Change of Higher School Tasks: the Impact on the Professional Teacher Competences. ICTERI, 281-287 [in English].

2. Dyshko, O., Zubekhina, T., Pavlyshyna, N. (2017). Informatsijno-komunikatsijni tekhnolohii $\mathrm{V}$ orhanizatsii elektronnoho navchannia bakalavriv (na prykladi spetsial'nostej «Turyzm» ta «Sotsial'na robota») [Information and Communication Technologies in the Organization of Bachelors' E-learning (using the case study of "Tourism" and "Social Work" as major subjects)]. Information Technologies and Learning Tools, 59 (3), 76-86 [in Ukrainian].

3. Bolubash, N. (2013). Orhanizatsijno-metodychni aspekty navchannia na bazi informatsijnoho seredovyscha Moodle [Organization and Methodology Aspects of Training within Moodle Platform]. Information technologies and teaching methods, 1(33) [in Ukrainian].

4. Kobysia, A. (2017). Informatsijne osvitnie seredovysche iak platforma dlia realizatsii zmishanoho navchannia u vyschykh navchal'nykh zakladakh. [Information Educational Environment as a Platform for Implementing Blended Learning in Higher Education Institutions]. Information Technologies and Learning Tools, 57(1), 75-82 [in Ukrainian].

5. Fahrutdinova, R., Yarmakeev, I., Fakhrutdinov, R. (2014). The formation of students? Foreign language communicative competence in learning English through interactive learning technologies (The study carried out at Kazan Federal University). English Language Teaching, 7(12), 36-46 [in English].

6. Dolyna, A. (2019). Vykorystannia systemy Moodle dlia vdoskonalennia fonetychnoi kompetentnosti majbutnikh uchyteliv anhlijs'koi movy [Improving pre-service foreign language teachers' phonological competence with Moodle]. Information Technologies and Learning Tools, 70(2) [in Ukrainian].

7. Ivanova, O. (2014). Informatsijno-komunikatsijni tekhnolohii u protsesi formuvannia profesijno oriientovanoi leksychnoi kompetentnosti [The Use of Information Technology in the Development of Professionally Oriented Lexical Competence]. Advanced Education, 1, 21-29 [in Ukrainian].

8. Beskorsa, O. (2017). Systema Moodle iak zasib orhanizatsii zmishanoho navchannia praktychnoi fonetyky nimets'koi movy [Moodle Virtual Learning Environment as a means of organizing blended learning in teaching practical phonetics of German language]. Information Technologies and Learning Tools, 62(6), 86-97 [in Ukrainian].

9. Osipova, N., Gnedkova, O., Ushakov, D. (2016). Mobile Learning Technologies for Learning English. ICTERI, 672-679 [in English]. 
10. Solomakha, A. (2019). Zastosuvannia slovnykovykh on-lajn trenazheriv dlia formuvannia inshomovnoi leksychnoi kompetentsii majbutn'oho pedahoha [The Use of Foreign Language Online Tutors to Form a Foreign Lexical Competency of a Pre-Service Teacher]. Educological discourse, 3-4, 143-155 [in Ukrainian].

11. Chainikova, G., Zatonskiy, A., Mitiukov, N., Busygina, H. (2018). The Development of Foreign Language Lexical Competence on the Basis of a Learner's Terminological Thesaurus and Dictionary. European Journal of Contemporary Education, 7(1), 51-59 [in English].

12. Byrdina, O., Dolzhenko, S., Yurinova, E. (2018). Formirovanie inojazychnoj kommunikativnoj kompetencii u studentov nefilologicheskih profilej podgotovki posredstvom content-based active speaking technology [The Formation of Foreign-Language communicative competence of non-philological students via content-based active speaking technology]. Novosibirsk State Pedagogical University Bulletin, 8(4), 7-25 [in Russian].

13. Potiuk, I. (2016). Metodyka formuvannia inshomovnoi leksychnoi kompetentnosti studentiv $\mathrm{v}$ umovakh stratehichnoho vyvchennia inozemnoi movy (komunikatyvnyj aspekt) [The methodology of forming students' foreign lexical competence based on the strategic learning of a foreign language (communicative aspect)]. The Proceedings of the National University of Ostroh Academy: Philosophy, 62, 280-283 [in Ukrainian].

14. Horbatiuk, L., Alieksieieva, H., Kravchenko, N., Lipych, V., Rozumna, T. (2019). Use of Mobile Applications for Foreign Language Lexical Competence Formation. Journal of History Culture and Art Research, 8(3), 113-124 [in English].

15. Gladka, O. (2018). Osoblyvosti rozvytku inshomovnoi leksychnoi kompetentnosti studentiv-filolohiv [The Features of Development of Foreign-Language Lexical Competence of Philological Students]. Research Bulletin. Series: Philological Sciences, 165, 455-459 [in Ukrainian].

16. Dolynskyi, Ye. (2015). Metodyka formuvannia inshomovnoi leksychnoi kompetentnosti za dopomohoiu posibnyka elektyvnoho kursu "Moia Frantsiia" [The Method of Forming Foreign Language Lexical Competence using Elective Course Textbook "My France"]. Problems of a Modern Textbook: collected works, 15(1), 179-186 [in Ukrainian].

17. Schmidt, V. (2009). Etapy formuvannia inshomovnoi leksychnoi kompetentsii studentiv nemovnykh spetsial'nostej [The Stages of Forming Foreign-Language Lexical Competency of Non-Linguistic Students]. Bulletin of the Petro Mohyla ChDU. Scientific works. Pedagogy, 95(108), 141-145 [in Ukrainian].

18. Zaichenko, I. (2014). Model' formuvannia anhlomovnoi leksychnoi kompetentnosti majbutnikh metalurhiv u protsesi navchannia profesijno oriientovanoho hovorinnia [The Model of Forming English Lexical Competence in Professionally Oriented Speaking of Future Metallurgists]. Visnyk of the Kyiv National Linguistic University (KNLU), Series “Pedagogy and Psychology”, 23, 119-128 [in Ukrainian].

19. Ternavs'ka, L., Shauerman, O. (2015). Formuvannia inshomovnoi leksychnoi kompetentnosti studentiv nemovnykh VNZ zasobamy frazeolohii [Lexical Competence Formation in Non-Linguistic Students Using English Phraseology]. Bulletin of Alfred Nobel University. Series "Pedagogy and Psychology", 1(9), 188-192 [in Ukrainian].

20. Smolina, S. (2010). Metodyka formuvannia inshomovnoi leksychnoi kompetentsii [Foreign Lexical Competence Formation]. Foreign Languages, 4, 16-23 [in Ukrainian].

21. Amelina, S. (2014). Metodyka formuvannia leksychnoi kompetentsii majbutnikh filolohiv [Formation Technique of Lexical Competence of Future Philologists]. Bulletin of Alfred Nobel University. Series "Pedagogy and Psychology", 2(8), 9-13 [in Ukrainian].

22. Bolubash, N. (2009). Teoretychni zasady formuvannia profesijnoi kompetentnosti majbutnikh ekonomistiv [Theoretical Basics of Forming Professional Competence of Future Economists]. Bulletin of the Petro Mohyla ChDU. Research papers. Pedagogy, 99 (112), 88-95 [in Ukrainian]. 
23. Nikolaeva, S. Yu. (Ed.) (2003). The Methods of Teaching Foreign Languages and Cultures: Theory and Practice: textbook for students of classical, pedagogical and linguistic universities. [The Methods of Teaching Foreign Languages and Cultures: Theory and Practice: textbook for students of classical, pedagogical and linguistic universities]. Kyiv: Lenwith [in Ukrainian].

24. Nikolaeva, S. Yu. (Ed.) (2003). Zahal'noievropejs'ki rekomendatsii z movnoi osvity: vyvchennia, vykladannia, otsiniuvannia [Pan-European Recommendations on Language Education: Study, Teaching, Assessment]. Kyiv: Lenwith [in Ukrainian].

25. Yarema, I. (2012). Contents of the formation of English lexical competence in professionally oriented speaking of students of metallurgical specialties. Collection of scientific works «Bulletin of Zaporizhzhia National University. Pedagogical Sciences, 1(17), 197-203 [in English].

Стрижак О. О. ${ }^{1}$, Крапівник Г. О. ${ }^{2}$

${ }^{1}$ Харківський національний економічний університет ім. С. Кузнеця, Харків, Україна

${ }^{2}$ Харківський національний педагогічний університет ім. Г. С. Сковороди, Харків, Україна

ЗАСТОСУВАННЯ ЗАСОБІВ ІНФОРМАЦЙНОГО СЕРЕДОВИЩА МООDLЕ ДЛЯ ФОРМУВАННЯ ІНШОМОВНОЇ ЛЕКСИЧНОЇ КОМПЕТЕНТНОСТІ

Стаття присвячена визначенню особливостей формування іншомовної лексичної компетентності на основі застосування засобів системи Moodle. Формування іншомовної лексичної компетентності розглянуто на прикладі викладання навчальної дисципліни Service Marketing для студентів магістратури денної форми навчання Харківського національного економічного університету ім. С. Кузнеця. Представлено приклад дистанційного курсу навчальної дисципліни Service Marketing. Описано структурні елементи навчальної дисципліни Service Marketing, надано їх зміст у розрізі формування професійних компетентностей. Обгрунтовано необхідність застосування інформаційно-комунікаційних технологій на основі функціоналу системи Moodle у процесі формування іншомовної лексичної компетентності. Описано елементи інформаційного середовища Moodle, які надають можливість сформувати термінологічний мінімум студента у професійній сфері.

Лексична компетентність передбачає не тільки з'ясування етимології та семантичного значення мовного знаку, але й вивчення особливостей його вживання в залежності від контенту. Ураховуючи це, запропоновано використання в освітньому процесі іншомовних матеріалів для розвитку професійної лексичної компетентності. У якості прикладу розглянуто завдання 3 аналізу телевізійного рекламного ролика англійською мовою та оцінювання ефективності реклами. Процедура проведення оцінки рекламного ролика передбачає його перегляд, визначення засобів та методів впливу рекламного ролика на свідомість споживача, зокрема за рахунок освоєння та аналізу мовної інформації. Обгрунтовано, що виконання завдання 3 перегляду та аналізу відеоматеріалу, окрім професійних компетентностей із навчальної дисципліни, сприяє розвитку мовленнєвих навичок та збільшує словниковий запас студента.

Також у статті визначено переваги та недоліки інформаційного середовища Moodle у процесі використання його для проведення лекцій, семінарських занять, самостійної роботи студентів, контролю знань та оцінювання результатів навчання.

Ключові слова: навчальна дисципліна, професійна компетентність, іншомовна лексична компетентність, інформаційне середовище Moodle

Стаття надійшла до редакції 24.10.2020

The article was received 24 October 2020 